\title{
AN EXPERIMENTAL STUDY FOR THE CHARACTERIZATION OF BIOGAS PRODUCTION FROM COW DUNG AND DROPPINGS
}

\author{
Younoussa Moussa Baldé, Cellou Kanté, Sette Diop, Sihem Tebbani
}

\begin{abstract}
The present work is an account of an ongoing work on biogas production from animal wastes at LEREA (Laboratoire d'enseignement et de recherche en énergétique appliquée) in Mamou, Guinea. The work consists of biogas production from anaerobic digestion and co-digestion of cow dung and droppings. We focus in this report on the determination of the physico-chemical characteristics of the experimental setup. We have carried out three experiments of anaerobic digestion each one lasting 45 days at mesophilic temperature (temperature was maintained in the range $27^{\circ} \mathrm{C}-28^{\circ} \mathrm{C}$ ). Biogas -28.4 liters have been obtained from droppings, 22.6 liters from cow dung and 38.7 liters from co-digestion of the previous two wastes. The following physico-chemical characteristcs were observed for cow dung: humidity $43 \%$, dry matter $20.83 \%$, organic matter $57 \%$, density $625 \mathrm{~kg} / \mathrm{m}^{3}$, carbon content $31 \%$, nitrogen content $1.46 \%$, nitrogen-carbon ratio $21 / 30$. For droppings we measured: humidity $35 \%$, dry matter $65 \%$, organic matter $62 \%$, density $250 \mathrm{~kg} / \mathrm{m}^{3}$, carbon content $36 \%$, nitrogen level $1.83 \%$. This characterization was carried out on a sample of $3 \mathrm{~g}$ of each type of substrate. These results agree with those of the literature that we were able to compare with.
\end{abstract}

Keywords: anaerobic digestion; anaerobic co-digestion; physico-chimical characterization; cow dung weste; droppings weste; methanation; animal waste

\section{INTRODUCTION}

In order to meet Guinea's energy needs, significantly reduce local pollution and the greenhouse effect, and preserve the environment, it is necessary to explore and develop new energy sources such as biogas. This widely available, inexpensive and non-polluting renewable energy can be used to complement so-called non-renewable fossil fuels $[15,9,16]$.

In Guinea, despite the importance of hydropower potential, the supply of thermal and electrical energy remains one of the major problems in most of the country's rural areas, leading to increased wood consumption, severe forest degradation, soil erosion and climate and environmental degradation. On the other hand, organic wastes may be turned into a source of wealth in remote rural areas thanks to anaerobic digestion. The biogas produced by this natural anaerobic digestion process may be used for the production of heat and electricity for households.

In addition, animal wastes, thanks to the organic matter they contain, are a guarantee for soil fertility. Farm animals release 20 to $40 \%$ of the nitrogen and phosphorus and 70 to $90 \%$ of the potassium ingested with feed. For poultry, the release is about $70 \%$ of the nitrogen $[3,8]$. The gaseous emissions from these effluents are methane, $\mathrm{CH}_{4}$, ammonia, $\mathrm{NH}_{3}$, hydrogen sulphide, $\mathrm{H}_{2} \mathrm{~S}$, carbon dioxide, $\mathrm{CO}_{2}$.

Recovering the biogas and agricultural fertilizer contained in these animal wastes requires prior characterization of their physico-chemical parameters $[11,5]$. This is the motivation of the first part of the work at LEREA. After the characterization of the samples we proceed to the methane production from the wastes. We provide experimental characterization of substrates consisting of cow dung and droppings that may be found in the area of Mamou in Guinea. Typical values of biogas production from cheap bioreactors are also provided by our study, including codigestion of cow dung and droppings.

We have carried out three experiments of anaerobic digestion each one lasting 45 days at mesophilic temperature (temperature was maintained in the range $27^{\circ} \mathrm{C}-28^{\circ} \mathrm{C}$ ). 28.4 liters have been obtained from droppings and 22.6 liters from cow dung and 38.7 liters from co-digestion of the previous two wastes. The following physicochemical characteristcs were observed for cow dung: humidity $43 \%$, dry matter $20.83 \%$, organic matter $57 \%$, density $625 \mathrm{~kg} / \mathrm{m}^{3}$, carbon content $31 \%$, nitrogen content $1.46 \%$, nitrogen-carbon ratio $21 / 30$. For droppings we measured: humidity $35 \%$, dry matter $65 \%$, organic matter $62 \%$, density $250 \mathrm{~kg} / \mathrm{m}^{3}$, carbon content $36 \%$, nitrogen level $1.83 \%$. This characterization was carried out on a sample of $3 \mathrm{~g}$ of each type of substrate. These results agree with those of the literature that we were able to compare with.

The paper is organized as follows. In next section we present the materials and methods used for characterization of the wastes as well as the biogas production. Section 3 is devoted to exposition of the results and their discussions. The paper ends with concluding remarks and words on future works. 


\section{MATERIALS AND METHODS}

The equipment used for the characterization consisted of an oven, a W10/10A-HERAUS incinerator of $800 \mathrm{~W}$, a $D I A L-O-G R A M$ brand analytical balance of $2610 \mathrm{~g}$ capacity, a stirrer glass for the agitation and homogenization of the substrate, a clamp allowing the manipulation of hot glassware, and two containers which are graduated in centiliters.

These equipments make it possible to measure the following characteristics: density, relative humidity, dry matter, organic matter, mineral matter, the carbon and nitrogen contents of the various cow dung and droppings saamples.

\subsection{Substrates}

The substrates used in this study consist of easily biodegradable organic wastes. Specifically, we chose cow dung, and droppings for their availability in the area of Mamou. Fig. 1 below shows plastic bags of samples of these wastes.

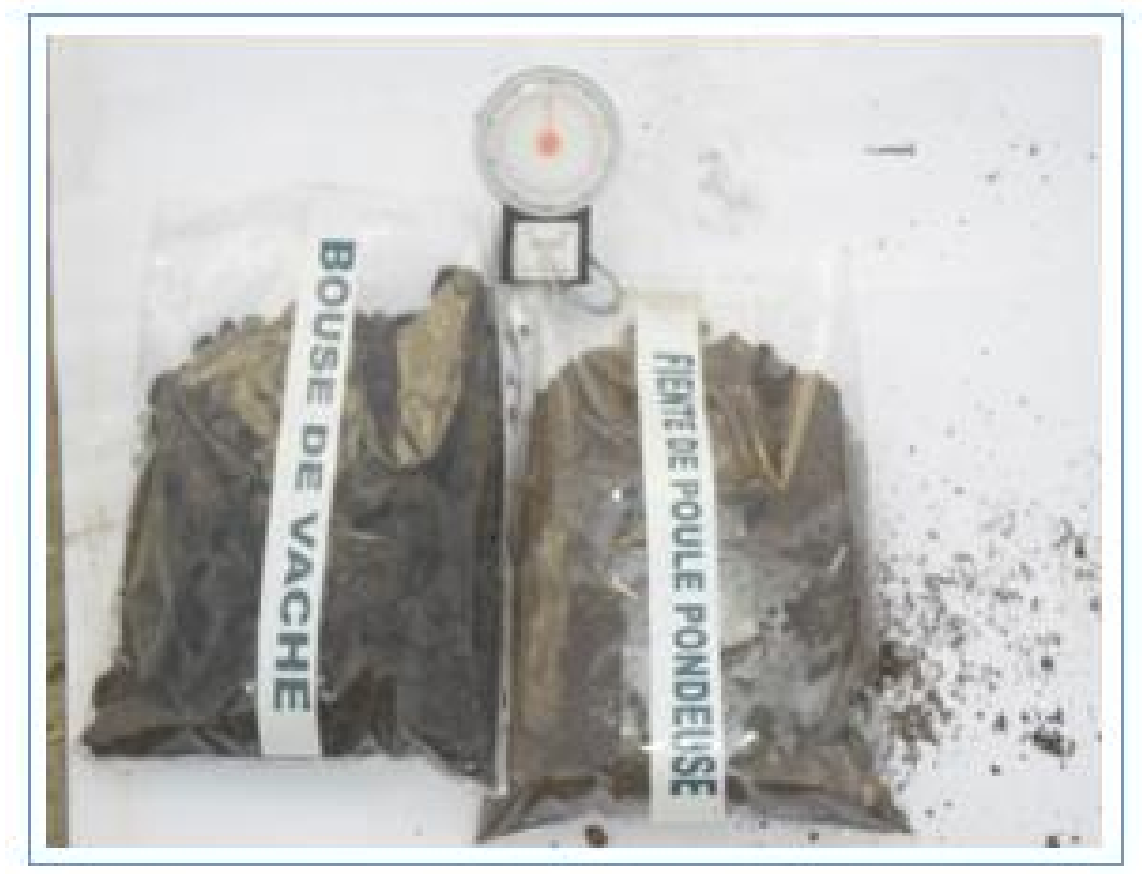

Fig. 1. Animal waste samples

Samples of cow dung and droppings are collected from a cattle park and a poultry farm in Mamou. The analysis of these samples was carried out at the Microbiology Laboratory of the National Control Office (ONCQ) of Matoto in Conakry. The results obtained were interpreted at LEREA facilities at UGANC in Conakry and in Mamou.

\subsection{Experimental setup}

This is a cheap poorman's bioreactor consisting of bottles of volume varying between 4.5 and 5 litters. The first one is the bioreactor itself. It is equipped with a flexible tube which lets the biogas leave the first bottle to a second one which is the container of the produced biogas. This bottle is initially filled with water. It is equipped with two holes: the first one is for the supply of gas from the bioreactor and the second hole lets the water flow to the third bottle which is a water collector. The principle of measurement of the biogas is thus very simple: under the biogas pressure in the biogas container the water flows to the water collector bottle. The latter is equipped with graduations measuring the displaced water and the volume of biogas produced, too. The photograph of Fig. 2 shows the three bioreactors each one made of the previously mentioned three bottles and diagram of Fig. 3 shows the principle of each bioreactor. Therefore, the digester is essentially a closed airtight and preferably thermally insulated vessel from the outside in which different bacterial species degrade the organic waste and produce biogas [18]. Therefore, our bioreactors are of batch type. 


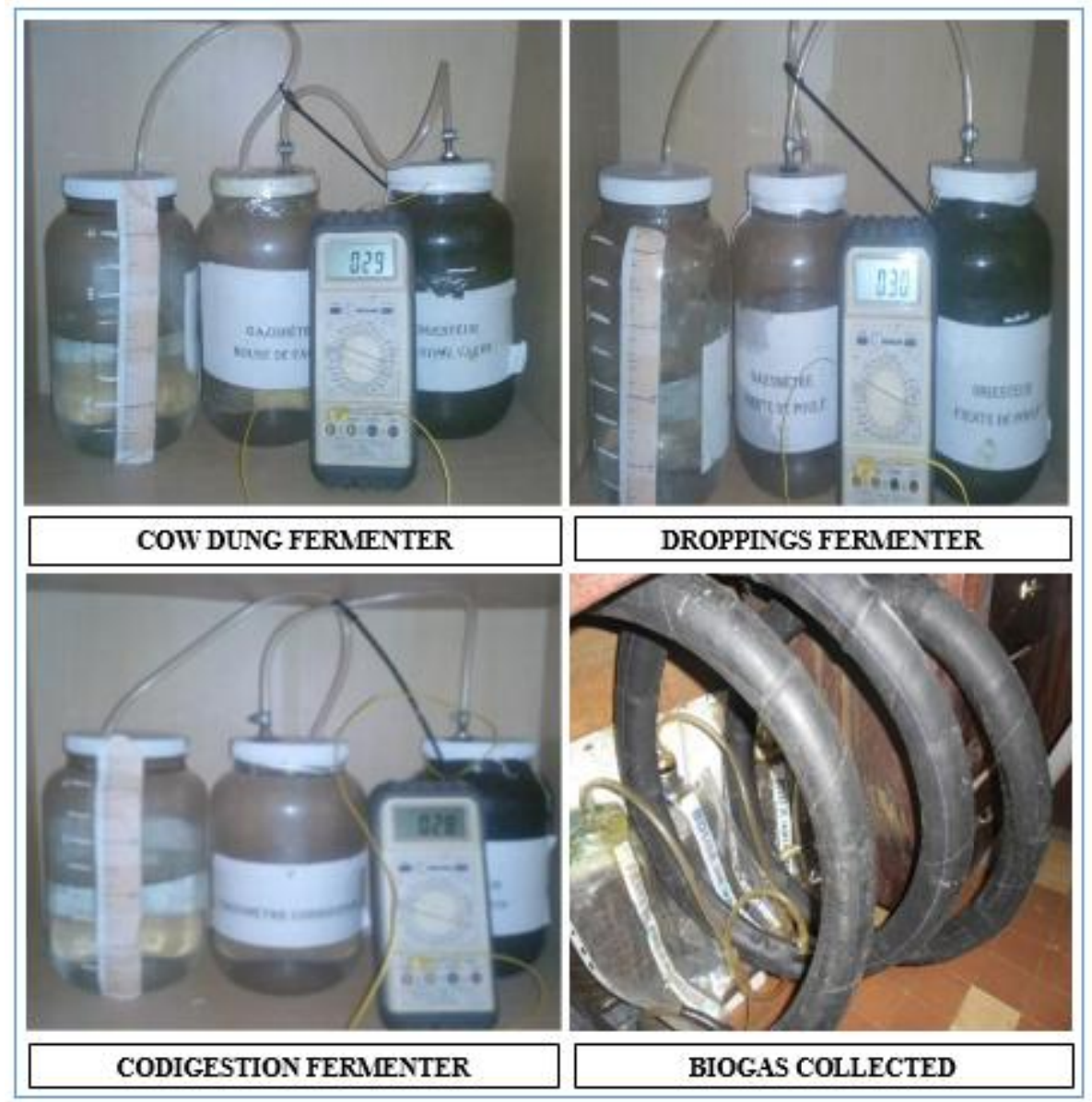

Fig. 2. Experimental method

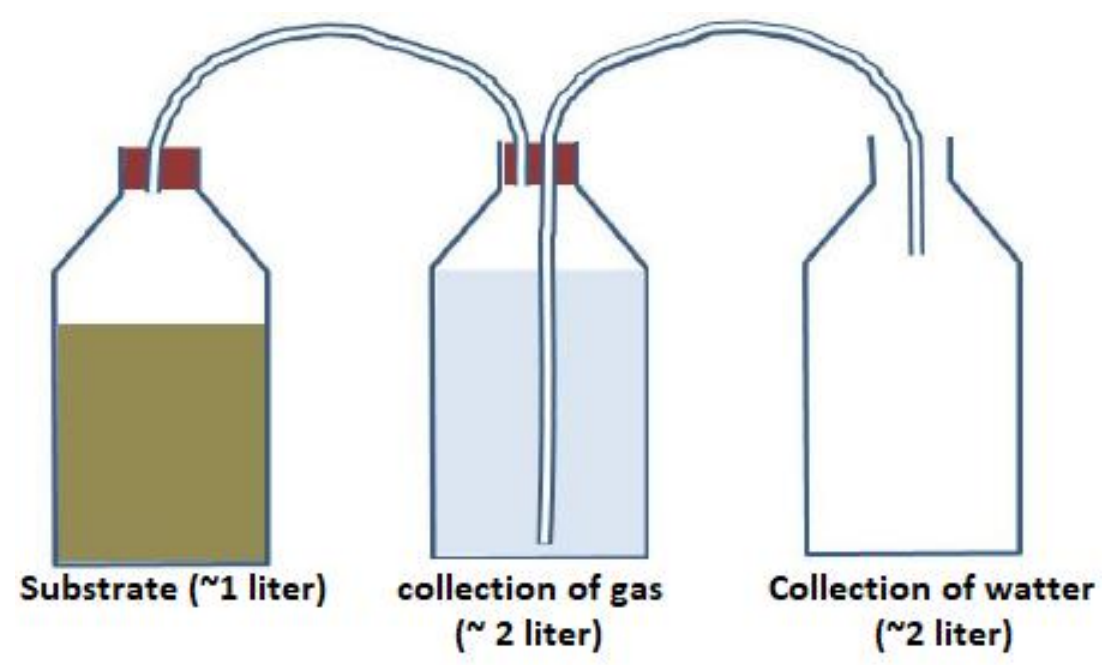

Fig. 3. Experimental setup

\subsection{Analytical methods}

Characterization of wastes is done through the two following methods: gravimetric and volumetric [12].

\subsubsection{Gravimetric method}

The gravimetric method consists of the determination of the following parameters: density, 
amount of organic matter, amount of mineral matter, moisture and the amount of dry matter.

\section{Density}

A glass vessel of 1 liter of volume is filled with organic waste without settlement and weighed on the scales. The average density $\left(\rho\right.$ in $\left.\mathrm{kg} / \mathrm{m}^{3}\right)$ is calculated according to the following formula

$$
\rho=\frac{m}{v} \#(1)
$$

\section{Organic Matter}

The determination of the rate of organic matter (MO) for each substrate consists of placing a sample of $20 \mathrm{~g}$ of each substrate in the oven for 24 hours at $70^{\circ} \mathrm{C}$. And then the calcination of samples of the $3 \mathrm{~g}$ previously dried for 2 hours in the incinerator. The rate of organic matter is determined according to

$$
\mathrm{MO}=\frac{\mathrm{Msec}-\mathrm{MSI}}{\mathrm{Msec}} \times 100 \#(2)
$$

where Msec is the weight (in g) before calcination and MSI the weight (also in g) after calcination.

\section{Mineral matter}

After 6 hours in incinerator, an inorganic residue is obtained. This mass of the waste calcined at 600 ${ }^{\circ} \mathrm{C}$ (MSI) is the mineral matter. Measuring the weight of the fraction of residual ash by the loss on ignition allows us to determine the percentage of the mineral contained in the waste. The mineral matter is determined by the equation

$$
\mathrm{MM}=\frac{\mathrm{MSI}}{\mathrm{Msec}} \times 100 \#(3)
$$

\section{Relative humidity}

The majority of protocols determine moisture by drying at temperature of $105^{\circ} \mathrm{C}$ to a constant weight. The moisture percentage of the different organic wastes is determined by the difference of weight of the sample before and after drying until the stabilization of the mass by formula [2]

$$
H=\frac{\text { MSo }- \text { Msec }}{\text { Mo }} \times 100 \#(4)
$$

where MSo is the initial mass of the sample, Msec the mass of the dried sample, $M_{\mathrm{H}_{2} \mathrm{O}}=M S o-M s e c$, the mass of water contained in the sample.

\section{Organic matter rate in the dry matter}

The organic matter content in the dry matter and in the initial substrate (MSo) are respectively determined by the relations

$$
\begin{gathered}
\% M O / M S=\frac{M O}{M S} \times 100 \#(5) \\
\% M O / M S o=\frac{M S-M M}{M S O} \times 100 \#(6)
\end{gathered}
$$

\subsubsection{Volumetric method}

The volumetric method consists of determining the organic carbon and nitrogen content.

\section{Organic carbon rate}

The organic carbon content in the sample was determined according to the content of organic matter according to the standard (NF44-161) by the relation [11]

$$
\begin{gathered}
\% C=\frac{\% M O}{1.725} \#(7) \\
\text { Nitrogen rate }
\end{gathered}
$$

\section{Nitrogen rate}

The total nitrogen content was determined by digesting $1 \mathrm{~g}$ of the sample with concentrated sulfuric acid in the presence of a catalyst (copper sulphate plus sodium sulphate) for 2 hours then distillation and titration of the ammonia released with a sulfuric acid solution of normal 0.02 concentration. En we use the relation

$$
\% N=V_{\text {titr }} \times 0.195 \times M_{\text {pes }} \#(8)
$$

where $V_{\text {titr }}$ is the titration volume in $(\mathrm{ml} / \mathrm{g}), M_{\text {pes }}$ is the test mass in $(\mathrm{g} / \mathrm{ml})$.

The analysis of these samples was carried out at the Microbiology Laboratory of the National Control Office (ONCQ) of Matoto in Conakry. The results obtained were interpreted at the laboratory LEREA in UGANC and in Mamou.

\subsubsection{Experimental procedures}

The determination of the densities consisted in filling a container of volume of waste ( $\mathrm{v}=1$ liter) without settlement and then weighed on balance. This amount of initial substrate is dried successively in the oven in five steps. Knowing the different masses (in g) we applied the formula (1) to calculate the different densities $\left(\rho\right.$ in $\left.\mathrm{kg} / \mathrm{m}^{3}\right)$, so the density of the substrate is the average of the densities coming from the five experiences.

The determination of the other parameters consists in carrying out successively five experiments on the same sample of $3 \mathrm{~g}$ of each type of substrate, until a constant mass of the sample is obtained. These experiments consist of successively introducing the dried $3 \mathrm{~g}$ sample into 
the muffle furnace and removing it after each hour, this operation is carried out 5 times on the same sample until a constant mass (MSI) is obtained which corresponds to the value of the fifth experiment.

At each operation, the MS is determined by weighing, the other parameters are determined by all the above relations. The averages of the five experiments represent the values of the physicochemical parameters of the substrate [11].

\subsubsection{The method of production of biogas}

This research concerns the determination of the amount of biogas contained in $1.5 \mathrm{~kg}$ of each type of substrate (cow dung and droppings) and the mixture of both substrates (co-digestion) in the proportion of one $(0.75 \mathrm{~kg})$ each. We simultaneously used 3 plastic bottles of 5 liters as digesters, they were filled up to $3 / 4$ of their volume respectively by the two types of substrate and their mixture. These samples were diluted in 2 liters of water each. These three digesters have been each connected to an air chamber (gasometer) through the flexible hoses of $8 \mathrm{~mm}$ interior diameter.

\section{RESULTS AND DISCUSSION}

3.1. Results and discussion of the characterization of animal wates

The tables below present the results obtained during the process of characterizing animal waste.

The results obtained show that the dry matter rates of the cow dung and droppings samples $(57 \%$ and $65 \%$ ) are relatively high compared to those given by [13] and [14] or $15 \%$ for cow dung and $30 \%$ for hen droppings.

The MO rate of cow dung 54\% MS and quite close to the result as reported by [14], ie $55 \% \mathrm{MS}$, and the MO rate of the hen droppings is $65 \% \mathrm{MS}$, results obtained by [10] is some $60 \% \mathrm{MO}$.

The carbon and nitrogen contents of the waste for cow dung 31\% and for droppings $36 \%$ respectively, the ratios of carbon and nitrogen $(\mathrm{C} / \mathrm{N})$ for these wastes are respectively 21 and 20 . These results show that the $\mathrm{C} / \mathrm{N}$ ratios of cow dung and hen droppings are close of the litterature. For some authors a ratio of $25 / 30$ is considered optimal for anaerobic digestion, while for others, $\mathrm{C} / \mathrm{N}$ ratios between 20 and 30 were critical for the stability of conversion processes, $[4,7]$.

Table 1: Characteristics of cow dung

\begin{tabular}{|c|c|c|c|c|c|c|c|}
\hline Sample & $(\mathbf{M S o}) \mathbf{g}$ & MSec(g) & MSI(g) & $\mathbf{H}(\%)$ & $\mathbf{M S}(\%)$ & $\mathbf{M O}(\%)$ & $\mathbf{~ k g / \mathbf { m } ^ { 3 }}$ \\
\hline 1 & 3 & 2.25 & 0.63 & 25.00 & 75.00 & 72 & 1000.00 \\
\hline 2 & 3 & 2.2 & 0.63 & 26.66 & 73.34 & 71 & 750.00 \\
\hline 3 & 3 & 2 & 0.63 & 33.33 & 66.67 & 69 & 666.00 \\
\hline 4 & 3 & 1.45 & 0.63 & 51.66 & 48.33 & 58 & 500.00 \\
\hline 5 & 3 & 0.625 & 0.63 & 79.17 & 20.83 & - & 208.00 \\
\hline Average & 3 & 1.72 & 0.63 & 43 & 57 & 54 & 625.00 \\
\hline
\end{tabular}

Table 2: Characteristics of droppings

\begin{tabular}{|c|c|c|c|c|c|c|c|}
\hline Sample & (MSo)g & MSec(g) & MSI(g) & H(\%) & MS(\%) & MO(\%) & $\mathbf{~ k g / \mathbf { m } ^ { 3 }}$ \\
\hline 1 & 3 & 2.63 & 0.5 & 13.00 & 87.00 & 72 & 333.00 \\
\hline 2 & 3 & 2.44 & 0.5 & 18.00 & 82.00 & 71 & 291.67 \\
\hline 3 & 3 & 2.25 & 0.5 & 25.00 & 75.00 & 69 & 270.83 \\
\hline 4 & 3 & 1.55 & 0.5 & 48.33 & 51.67 & 58 & 208.33 \\
\hline 5 & 3 & 1.88 & 0.5 & 38.00 & 62.00 & - & 250.00 \\
\hline Average & 3 & 2.14 & 0.5 & 35 & 65 & 62 & 271.00 \\
\hline
\end{tabular}


Table 3: Chemical characterization of cow dung

\begin{tabular}{|c|c|c|c|c|c|}
\hline Experiment & $\mathbf{V t i t}(\mathbf{m l} / \mathbf{g})$ & $\mathbf{M S e c}(\mathbf{g} / \mathbf{m l})$ & $\mathbf{C}(\%)$ & $\mathbf{N}(\%)$ & $\mathbf{C} / \mathbf{N}$ \\
\hline 1 & 45 & 1.5 & 42 & 1.46 & 28.50 \\
\hline 2 & 5.00 & 1.5 & 41 & 1.46 & 28.30 \\
\hline 3 & 5.00 & 1.5 & 40 & 1.46 & 27.20 \\
\hline 4 & 5.00 & 1.5 & 30 & 1.46 & 23.00 \\
\hline 5 & 5.00 & 1.5 & - & 1.46 & - \\
\hline Average & 5.00 & 1.5 & 31 & 1.46 & 21.40 \\
\hline
\end{tabular}

Table 4: Chemical characterization of droppings

\begin{tabular}{|c|c|c|c|c|c|}
\hline Experiment & $\mathbf{V t i t}(\mathbf{m l} / \mathbf{g})$ & $\mathbf{M S e c}(\mathbf{g} / \mathbf{m l})$ & $\mathbf{C}(\mathbf{\%})$ & $\mathbf{N}(\%)$ & $\mathbf{C} / \mathbf{N}$ \\
\hline 1 & 5.00 & 1.88 & 47 & 1.83 & 25.66 \\
\hline 2 & 5.00 & 1.88 & 46 & 1.83 & 25.00 \\
\hline 3 & 5.00 & 1.88 & 45 & 1.83 & 25.00 \\
\hline 4 & 5.00 & 1.88 & 43 & 1.83 & 23.00 \\
\hline 5 & 5.00 & 1.88 & - & 1.83 & - \\
\hline Average & 5.00 & 1.88 & 36 & 1.83 & 20.00 \\
\hline
\end{tabular}

Table 5: Physico-chemical characteristics of the 2 wastes compared

\begin{tabular}{|c|c|c|c|c|c|c|c|}
\hline Type of waste & $\mathbf{H}(\%)$ & $\mathbf{M S}(\%)$ & $\mathbf{M O}(\%)$ & $\mathbf{M V}\left(\mathbf{k g} / \mathbf{m}^{\mathbf{3}}\right)$ & $\mathbf{C}(\mathbf{\%})$ & $\mathbf{N}(\%)$ & $\mathbf{C} / \mathbf{N}$ \\
\hline Cow dung & 43 & 57 & 54 & 625 & 31 & 1.46 & 21.40 \\
\hline Droppings & 35 & 65 & 62 & 271 & 36 & 1.83 & 20.00 \\
\hline
\end{tabular}

\subsection{Results and discussion of the biogas production}

The table below illustrate the results obtained during the process of experiments animal wastes, with:

Table 6: Biogas produced by intrans (in liters)

\begin{tabular}{|c|c|c|c|c|c|c|c|}
\hline Sample & (MSo)g & MSec(g) & MSI(g) & H(\%) & MS(\%) & MO(\%) & $\mathbf{~ k g / \mathbf { m } ^ { 3 }}$ \\
\hline 1 & 3 & 2.25 & 0.63 & 25.00 & 75.00 & 72 & 1000.00 \\
\hline 2 & 3 & 2.2 & 0.63 & 26.66 & 73.34 & 71 & 750.00 \\
\hline 3 & 3 & 2 & 0.63 & 33.33 & 66.67 & 69 & 666.00 \\
\hline 4 & 3 & 1.45 & 0.63 & 51.66 & 48.33 & 58 & 500.00 \\
\hline 5 & 3 & 0.625 & 0.63 & 79.17 & 20.83 & - & 208.00 \\
\hline Average & 3 & 1.72 & 0.63 & 43 & 57 & 54 & 625.00 \\
\hline
\end{tabular}




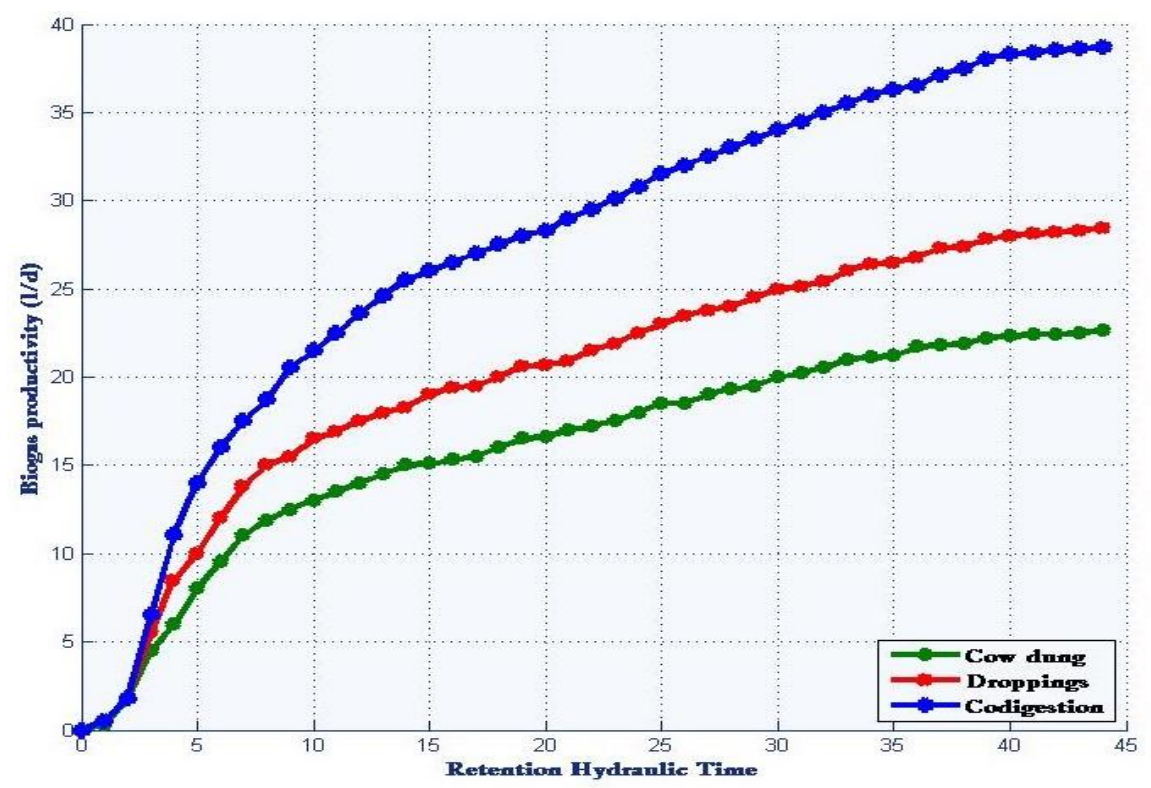

Fig. 4. Kinetics of cumulative biogas (Liter/day)

Biogas production started on the 3rd day after the digester load and lasted 45 days. The biodegradation of organic substrate into gaseous compounds occurs as follows:

(i) over a period of 45 days, $50 \%$ of the total volume of gas is produced in 9 days with a maximum on the 9th day of fermentation;

(ii) the continuous fermentation process from the 10th to the 45th day. After 45 days of methanation in a temperature range of $27^{\circ} \mathrm{C}$ to $28^{\circ} \mathrm{C}$, the amount of biogas for droppings is 28.4 liters, higher than that of cow dung 22.6 liters. Codigestion gives a higher value 38.7 liters. On average, the daily specific biogas production of the different animal wastes is: cow dung (0.50 liter/day), droppings (0.63 liter/day) and finally co-digestion $(0.86$ liter/day $)$ at an average temperature of $28^{\circ} \mathrm{C}$. The resultats of the literature give an average production of 18 liters to 20 liters for cow dung and 19 liters to 40 liters for the droppings [1].

\section{CONCLUSION}

This research shows the importance of the knowledge of certain physico-chemical parameters of wastes in order to improve their productivity in biogas. This study also documents the fact that codigestion is a factor of optimization of biogas production by anaerobic digestion. Future work tries to improve all these experimental procudures which were described in this paper. One of the objectives is to be able to deliver to decision makers reliable quantitative evaluation of energetic potentialities of animal wastes, and other waste types, too. Ongoing work also concerns modeling of dynamics of anaerobic digestion $[6,17]$ of animal wastes which are produced in the area of Mamou.

ACKNOWLEDGEMENT: The French Embassy in Guinea is acknowledged for their financial support of Younoussa Moussa Baldé.

\section{REFERENCES}

1. Aboubakar, Z. Boli and C.M.F. Mbofung, Etude du potentiel biogaz des déjections animales: bouses de bovins et fientes de volailles d'un centre zootechnique à Maroua - Cameroun, Revue des Energies Renouvelables, 19 (2016), 447-464.

2. Amaranth, João Alberto Lima, Biomethanization of Municipal Putrescible Waste-Available Technologies and Challenges for Quebec. University of Sherbrooke, 99 (2010).

3. Castaing, J., P. Pouech and R. Coudure, Digestion anaérobie anaérobique de lisiers de porc en mélange avec les déchets agro-industriels, Journée de la Recherche Porcine, 34 (2002), 195-202.

4. Claire Chottier, Composés Organiques Volatils du Silicium et sulfured'hydrogène - Analyse Traitement - Impact sur la valorisation des biogaz, https://tel.archives-ouvertes.fr/tel-00715818, 2012, 38-41.

5. De Baere, L. Will, Anaerobic digestion of solid waste survive in the future, Water Science and Technology, 200(2006), 187-194.

6. Dinova, N., M. Belouhova, I. Schneider and Y. Topalova, Functional control of the technologies for biogas production, Ecological Engineering and Environment Protection, 1 (2016), 52-64.

7. Gunaseelan, V. N. Regression models of ultimate methane yields of fruits and vegetable solid wastes, sorghum and napiergrass on chemical composition, Bioresource Technology, 98 (2007), 1270-1277. 
8. Held, C., M. Wellacher, K. Robra, G.M. Gubitz, Two-stage anaerovic fermentation of organic waste in CSTR and UFAF-reactors, Bioressource Technology, 81 (2002), 19-24.

9. Kabaivanova, L., I. Simeonov, D. Denchev, S. Mihaylova, V. Hubenov, R. Nikolova and D. Todorova, Thermochemical pretreatment of lignocellulosic substrates for anaerobic digestion at mesophilic and thermophilic conditions, Ecological Engineering and Environment Protection, 2(2016), 42-49.

10. Lacour, J., R. Bayard, E. Emmanuel, R. Gourdon, Evaluation du potentiel de valorisation par digestion anaérobie des gisements de déchets organiques d'origine agricole et assimilés en Haïti, Déchets - Revue Francophone d'Écologie Industrielle, 60 (2011).

11. M'Sadak, Y. and A. Ben M'Barek, Caractérisation quantitative du digestat solide de la biométhanisation industrielle des fientes avicoles et alternatives de son exploitation agronomique hors sol, Revue des Energies Renouvelables, 16(2013), 33-42.

12. M'Sadak, Y. and A. Ben M'Barek, and L. Tayachi, Possibilités d'Incorporation du Méthacompost Avicole dans la Confection des Substrats de Culture à Base de Compost Sylvicole en Pépinière Forestière, Revue Nature et Technologie, 6 (2012), 59-70.
13. Parra, R., A. Escobar, Use of fibrous agricultural residues (FAR) in ruminant feeding in Latin America. In: FAO. Better utilization of crop residues and by-products in animal feeding: research guidelines - State of knowledge. Rome, 1985, pp. 213.

14. Parra, R., A. Escobar, E. Gonzalez, El potencial de los recursos agricolas fibrosos. Jornadas Agronomicas, Maracay, Venezuela, 11(1977), 12-15.

15. Rakotoniaaina, V.A., Co-méthanisation des déchets fermiers et alimentaires: experimentation et modelisation, thèse Université de la Réunion, 2012.

16. Traoré, D., D. Dianou and A. S. Traoré, Biomethane Potential of Some Agroresources in Burkina Faso: Case Study of Vegetable Residues, Pig Manure, Mango Waste and Bovine Manure, Journal of Advances in Biology and Biotechnology, 15 (2017), 1-11.

17. Ward, A.J., P.J. Hobbs, P.J. Holliman, D.L. Jones, Optimisation of the anaerobic digestion of agricultural resources. Bioresource Technology, 99(2008), 7928-7940.

18. Yong, Zihan, Yulin Dong, $\mathrm{Xu}$ Zhang and Tianwei Tan, Anaerobic co-digestion of food waste and straw for biogas production, Renewable Energy, 78(2015), 527-530.

\title{
ЕКСПЕРИМЕНТАЛНО ИЗСЛЕДВАНЕ НА ПОЛУЧАВАНЕТО НА БИОГАЗ ОТ КРАВЕШКИ И ПТИЧИ ТОР
}

\author{
Йонуса Муса Балде, Целу Канте, Сет Диоп, Сихем Тебани
}

Резюме. Настоящата статия е равносметка на продължаващата работа за производство на биогаз от животински отпадъци в LEREA (Лаборатория за обучение и научни изследвания в приложната енергетика) в Маму, Гвинея. Работата се сьстои в производство на биогаз чрез анаеробна биодеградация на кравешки тор и смеси от птичи и кравешки тор. В този доклад се фокусираме върху определянето на физико-химичните характеристики на експерименталната установка. Проведени бяха три експеримента на анаеробна биодеградация, като всеки един от тях бе с продължителност 45 дни при мезофилна температура (температурата се поддържа в диапазона $27^{\circ} \mathrm{C}-28^{\circ} \mathrm{C}$ ). Добивите на биогаз бяха както следва: 28.4 литра са получени от птичия тор, 22.6 литра от кравешкия тор и 38.7 литра от сместта на предишните две отпадъци. Физико-химичните характеристики за кравешкия тор са следните: влажност 43 $\%$, сухо вещество $20.83 \%$, органична материя 57\%, пльтност 625 кг м $^{3}$, съдържание на въглерод $31 \%$, съдържание на азот $1.46 \%$, съотношение въглерод/азот 21/30. За птичия тор те са: влажност $35 \%$, сухо вещество $65 \%$, органична материя $62 \%$, пльтност 250 кг $\mathrm{M}^{3}$, съдържание на въглерод 36\%, съдържание на азот 1.83\%. Тези характеристики са получени от проба от 3 г от всеки субстрат. Получените резултати са подобни на известните от литературата.

Ключови думи: анаеробна биодеградация, моно- и смесени субстрати, физико-химични характеристики, кравешки тор, птичи тор, метанизация

\section{Sette Diop and Sihem Tebbani}

Laboratoire des signaux \& systèmes

CNRS - CentraleSupélec - Université Paris-Sud -

Université Paris Saclay

3 rue Joliot Curie

91192 Gif sur Yvette cedex, France

E-mails: Diop@L2S.CentraleSupelec.fr,

Sihem.Tebbani@CentraleSupelec.fr

\section{Younoussa Moussa Baldé}

Laboratoire d'enseignement et de recherche en énergétique appliquée and the Laboratoire des signaux \& systèmes. E-mail: YouMoussa.Balde@L2S.CentraleSupelec.fr

\author{
Cellou Kanté, Director \\ Institut supérieur de technologie de Mamou \\ Laboratoire d'enseignement et de recherche en \\ énergétique appliquée \\ Université Gamal Abdel Nasser de Conakry (UGANC) \\ BP 063Mamou, Guinea \\ E-mail: CelKante@yahoo.fr
}

